\title{
Paradigm Shift in the Concept of Workforce Diversity: A Key to increase the Organizational Efficiency
}

\author{
Pooja Aggarwal
}

\begin{abstract}
Workplace diversity refers to the commonalities and contrasts among individuals at work in terms of class, nationality, age, ethnic heritage, academic background, physical capabilities and impairments, gender, interpersonal, and psychological variables. As a result, organizations must create an environment that is compatible with the diversification of their workforce in order to improve their efficiency in this globalised era. The goal of managing workforce diversity is to build and keep a favorable work environment where each employee's contributions are recognized. This research paper critically analyses workforce diversity and its paradigm shift over time in the context of an organization. Furthermore, this planned research intends to investigate of workplace diversity and its impact on an organization's efficiency. This study's research will be solely collected from secondary sources. The research study's findings will be beneficial to the organization since they provide some guidelines and recommendations that can be utilized to develop effective paradigms for managing diversity in the workplace. The proposed research study concludes with the belief that appropriate handling of workplace diversity may lead to more committed, pleased, and high-performing employees, as well as make the organization a more efficient workplace.
\end{abstract}

Keywords: Diversity, Organizational Efficiency, Workforce, Paradigms, Organization

\section{INTRODUCTION}

The integration and esteem of each employee in the organization make up the concept of workplace diversity. It entails comprehending the fact that each individual is distinct and appreciating the differences among them. These ideologies can be categorised by caste, regXXion, gender, socioeconomic background, age, physical abilities, religious convictions, political preferences, or other factors. Workplace diversity is the process of building a supportive environment in which individuals' various abilities, cultural perspectives, and backgrounds are valued. A variety of factors, including age, ethnicity, gender, disability, language, religious views, gender identity, intersex status, life stages, and education, are responsible for shaping people's perspectives. It is the presentation of these disparities in a supportive, safe, and encouraging atmosphere. It's about getting to know one other and going beyond simple

Manuscript received on September 16, 2021.

Revised Manuscript received on October 03, 2021.

Manuscript published on October 30, 2021.

* Correspondence Author

Dr. Pooja Aggarwal*, School of Management, Babu Banarasi Das University, Lucknow (U.P), India. Email: poojaggarwal14@bbdu.ac.in

(C) The Authors. Published by Blue Eyes Intelligence Engineering and Sciences Publication (BEIESP). This is an open access article under the CC BY-NC-ND license (http://creativecommons.org/licenses/by-nc-nd/4.0/)

endurance to embracing and applauding the many aspects of diversity that dwell inside each personality. Diversity is an array of conscientious practises that entails comprehending and appreciating the mutuality of compassion, civilizations, and the global ecosystems; acknowledging the diversity of not only ways of being, but also methods of understanding; social, communal, and institutional racism produces and maintains advantages for some while producing and company. It considers ethnicity, gender, racial background, programming, education, culture, and other factors.

\section{LITERATURE REVIEW}

Due to increased globalization, greater workforce variety, and the increasing complexity of jobs, workforce diversity has had a crucial role in organizational life in the past decade (Williams and' Reilly, 1998). While William and Reilly (1998) defined diversity as the level of variability amidst members of the team on selected demographic parameters, their theory attempts to explain how such diversity affects team effectiveness and strategies. Thomas and Ely (1998) argue that diversity should be characterized as various ethnic communities bring to the table. Multiplicity, according to Cox (001), is "the diversity of social and cultura ntities among people that want to live together in a employment or marketing context." Workforce diversity was studied by Henry and Evans (2007) to see how it affects an organization's success. According to Anda (2010), the effect of cross-culture management plays a very significant role in the efficiency of an organization. Differen scholars consider workforce diversity management as shared.

\section{THE GAP IN LITERATURE}

Up to this point, a large number of previous studies on the concept of labour force diversification had been carried out. Several studies have looked into managing diversity to examine if it improves organisational performance or effectiveness, as well as the challenges that come with workplace diversity. The concept of heterogeneity is an expansive one with many alternative perceptions. Various research scholars have described it in a number of ways.

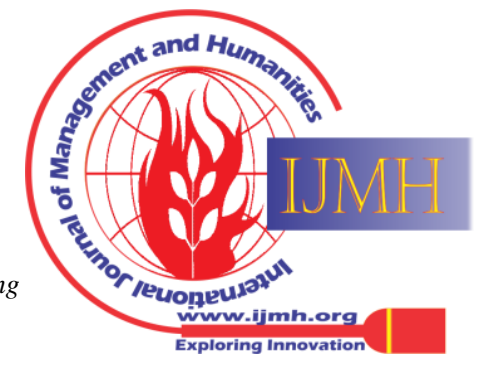


Regardless of the fact that multiculturalism looks to be gaining traction in modern organisations in recent years, few studies have examined its impact on business goals. According to Kundu and Mor, employees' attitudes of gender diversity promotion were favourably associated to organisational success (2017). Cultural diversity, team building, and group training, according to dita and Egbule (2015), mediate the connection between corporate effectiveness and workforce diversity. As per the research study of Suri and Sharma in 2011, there is a significant relation between cross-culture management and its impact over the efficiency of the organization. However, it's unclear whether any academia has looked into the impact of diversity management methods on organisational efficiency. However, none of the prior studies had sought to explain the advantages of workplace diversity, notably employees' contributions to operational productivity as a result of their diverse perspectives.

\section{RESEARCH METHODOLOGY}

This research of the theoretical model is solely based on secondary data acquired from a variety of sources. The information is produced from publicly available research from a lot of disciplines, which can be found on their websites and in their reports. Data has been gathered from many books, research journals, research papers, articles, and other print media to the detailed understanding of the subject dependability of the information. The researcher used standard, mostly unaltered data extraction forms to extract data automatically.

\section{FINDINGS AND RECOMMENDATIONS}

It was created after evaluating and thoroughly studying the literary works as well as several research papers on workforce diversity and its impact on businesses from various writers, it has been determined that an organisation should handle diversity in the workplace adequately because of an incompetence to do so can lead to various issues within the organisation. Inability to effectively manage workforce diversity can be a source of job discontentment and a decrease in employee 's performance. In this research study, it was discovered that while employing a multicultural workforce is critical in today's scenario, managing such a workforce is a major challenge. Hiring a diverse workforce will improve the organization's efficiency. After considering all of the data in this research study, it is necessary to recommend some appropriate ways to deal with the shortcomings. On the one hand, we say that we should incorporate new trends into HR policies, while on the other hand, Workplace diversity, for example, is seen as a concern in the most current fad. The study came up with a few recommendations that could help to limit the challenges that come with workforce diversity. However, by establishing a number of regulations, such as encouraging employees to use common language in the workplace, this problem can be remedied, and providing a variety of motivational and mentoring programmes for employees and last but not the least that Employees are required to participate in managerial activities and decisions of the organization. It's also crucial to remember that diversity in the workplace is all about justice. As a result, in order to promote efficiency, equality must be maintained throughout the organisation.

\section{CONCLUSION}

Managing workforce diversity quickly and successfully will undoubtedly be a winning situation for any organization looking to grow and succeed. Age, gender, and race aren't the only factors that contribute to cultural diversity at work. As a consequence, the ability of an organisation to effectively manage its diverse personnel is highly impactful in terms of organisational development and success. Since people are gifted differently, workplace diversity helps to facilitate communication in a variety of deficiencies in the workplace. Because one's weakness will be compensated by the strength of others among the organization's employees, this is a long-term process. An organisation that values diversity in the workplace will attract a broader range of candidates to its openings because it will be seen as a more progressive organisation that welcomes people from all walks of life. As a result, it's crucial to focus on each person's skills and collaborate with the rest of the team. As a result, a good mix of workforce diversity will establish a positive symbiosis for organisational efficiency.

\section{REFERENCES}

1. Aswathappa, K. (2005), Human Resource and Personnel Management Text and Cases, 4th ed. p 467.

2. 2- Dessler, G. (2005,) Human Resource Management, 10th ed, New Jersey: Pearson Prentice Hall.

3. Dwivedi, S. R. (2006) Managing Human Resource Personnel Management in Indian Enterprises, 2nd ed.

4. Gupta, C. (2006), Human Resource Management, New Delhi: Sultan Chand and Sons

5. Prasad, L. (2005), Human Resource Management, 2nd ed., New Delhi: Sultan Chand and Sons.

6. Gupta. C.B. (2008). Human Resource Management, Sultan Chand \& Sons, p. 7.3.

7. Yousuf Kamal and Most. Moriom Ferdousi, "Managing Diversity at Workplace: A Case Study of hp", ASA University Review, Vol. 3 No. 2, July-December, 2009

8. Ankita Saxenaa, "Workforce Diversity: A Key to Improve Productivity", Symbiosis Institute of Management Studies Annual Research Conference (SIMSARC13)

9. Ajiri Peter Samuel and Hillary Odiakaose Odor, "Managing Diversity at Work: Key to Organisational Survival", European Journal of Business and Management www.iiste.org, ISSN 2222-1905 (Paper) ISSN 2222-2839 (Online), Vol.10, No.16, 2018

10. Donatus I. Amaram, "Cultural Diversity: Implications For Workplace Management", Journal of Diversity Management - Fourth Quarter 2007 Volume 2, Number 4

11. Shreelatha R. Rao and Dr. M. M. Bagali, "Workforce diversity and management: An emphirical study on relationship between diversity management practices, obstacles and acceptance of gender diversity among employees in IT industry; Bangalore", IOSR Journal of Business and Management (IOSR-JBM) e-ISSN: 2278-487X, p-ISSN: 2319-7668. Volume 16, Issue 2. Ver. I (Feb. 2014), PP 12-25

12. www.scribd.com

13. www.hrpub.org

14. http://onlinelibrary.wiley.com

15. http://www.tandfonline.com

16. https://www.nepjol.info

17. https://pdfs.semanticscholar.org

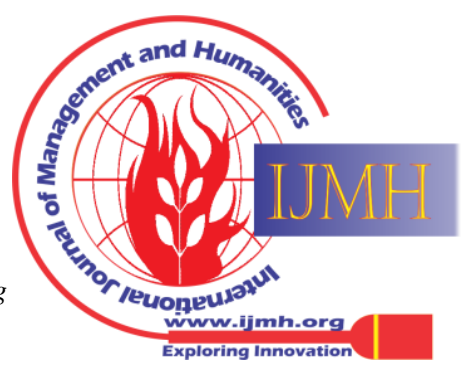




\section{AUTHOR PROFILE}

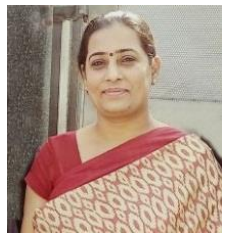

Dr. Pooja Aggarwal, Associate Professor, School of Management, Babu Banarasi Das University, Lucknow, Uttar Pradesh. She has a teaching experience of 15 years at both Undergraduate and Postgraduate levels in Bharti Vidhyapeeth Institute of Management Research, New Delhi as well as in the University of Lucknow and Dr. A.P.J. Abdul Kalam Technical University, Lucknow affiliated College in Lucknow, U.P. She holds a Doctorate in Commerce. Besides being a Double Graduate in B.Com and LL.B., she also has a Triple Post-Graduate in MBA, M.Com. and LL.M. She also has a Post Graduate Diploma in International Business Operation. She is UGC NET (Commerce) qualified. Her areas of interests are HRM, Business Laws, Labour Laws and International Business. She has participated in and presented various research papers in National and International seminars and conferences. She has also conducted online webinars as a convener during the Covid-19 Pandemic. She has authored a book titled "20 Short Case Studies on Management and Organizational Behaviour (In Indian Context) and Co-Authored two books entitled "Company Law and Secretarial Practice", and "Business Operation". Besides she has various articles to her credit which are published in various national and international journals as well as numerous chapters in referred books. She is also a fellow member of the Indian Academic Researchers Association (IARA). Apart from teaching, she has held several administrative positions like Academic Coordinator, Head Department of Management, Head of Student Welfare Cell, Member of Discipline Committee, Head In-Charge Academic Club, and Head In-Charge for Research Projects.

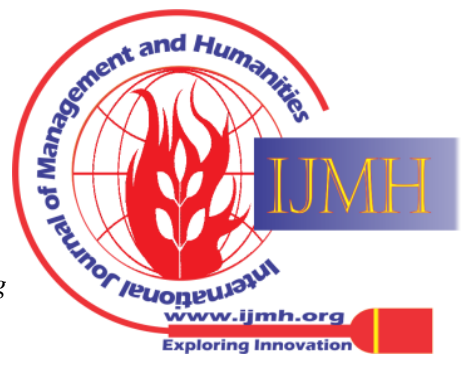

